\title{
The Opening of John's Narrative (John 1:19-2:22)
}

Historical, Literary, and Theological Readings from the Colloquium Ioanneum 2015 in Ephesus

Ed. by R. Alan Culpepper and Jörg Frey

[Der Anfang der johanneischen Erzählung (Joh 1:19-2:22). Historische, literarische und theologische Lektüren vom Colloquium loanneum 2015 in Ephesus.]

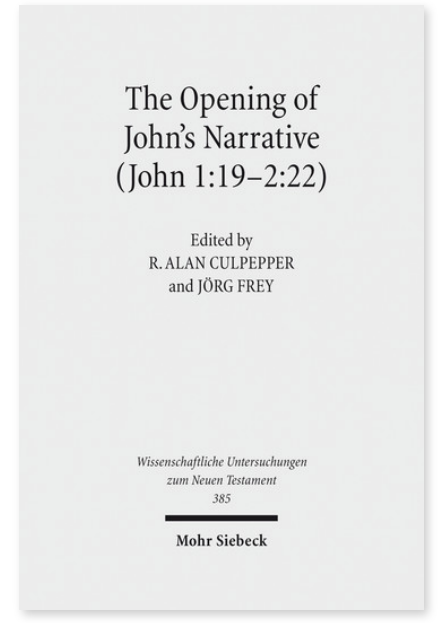

2017. XXI, 377 Seiten. WUNT I 385

ISBN 978-3-16-155663-0 DOI 10.1628/978-3-16-155663-0 eBook PDF 169,00€

ISBN 978-3-16-155262-5

Leinen $169,00 €$
Veröffentlicht auf Englisch.

Die Beiträge dieses Bandes vermitteln wichtige Einsichten zum Johannesevangelium und zur gegenwärtigen Johannesforschung. Der Anfang der johanneischen Erzählung bietet komplexe exegetische Probleme. Der Erzähler führt das Zeugnis des Täufers ein und bleibt dann völlig im Hintergrund. Welche Funktion hat das Jesajazitat? Welche Bedeutung haben die Reinigungsriten bei Johannes? Wer ist der ungenannte Jünger? Was bedeutet der Titel »Lamm Gottes«? Was sind die "größeren Dinge«, die die Jünger sehen sollen? Welche Rolle spielen die aufsteigenden und absteigenden Engel? Und wie ist Jesu brüske Antwort an seine Mutter zu verstehen? Einige der Beiträge des Bandes fragen, wie die Szenen dieser Kapitel in Ephesus gelesen werden konnten, so die Erzählungen von der Hochzeit zu Kana oder von Jesu prophetischem Auftritt im Tempel. Die Beiträge erläutern weiter, wie das Evangelium einerseits kreativ Traditionen aufnimmt und weiterentwickelt und andererseits seine Leserinnen und Leser aktiv in den Dialog mit dem Text zieht.

\section{Inhaltsübersicht}

George L. Parsenios: The Testimony of John's Narrative and the Silence of the Johannine Narrator - Christos Karakolis: Recurring Characters in John 1:19-2:11: A Narrative-Critical and Reader-Oriented Approach - Catrin H. Williams: The Voice in the Wilderness and the Way of the Lord: A Scriptural Frame for John's Witness to Jesus - Marianne Meye Thompson: Baptism with Water and with Holy Spirit: Purification in the Gospel of John - Ruben Zimmermann: Jesus - the Lamb of God (John 1:29 and 1:36): Metaphorical Christology in the Fourth Gospel - Udo Schnelle: Der ungenannte Jünger in Joh 1:40 - William Loader: John 1:51 and Johannine Christology - Jan G. van der Watt: Angels in John 1:51 - Jörg Frey: Das prototypische Zeichen (Joh 2:1-11): Eine Kommentar-Studie - Craig R. Koester: The Wedding at Cana (John 2:1-11): Reading the Text in the Cultural Context of Ephesus - Adele Reinhartz: A Rebellious Son? Jesus and His Mother in John 2:4 - Michael Theobald: Raum- und Zeitkonstruktion im Johannesevangelium. Zugleich ein Beitrag zur expositionellen Funktion der Erzählung von der Tempelreinigung Joh 2,13-22 - Jean Zumstein: Johannes 2,13-22 im Plot und in der Theologie des vierten Evangeliums - $R$. Alan Culpepper: Temple Violation: Reading John 2:13-22 at the Temple of Artemis in Ephesus

R. Alan Culpepper Born 1946; PhD from Duke University; taught at the Southern Baptist Theological Seminary, Baylor University, and Mercer University, founding dean of the McAfee School of Theology at Mercer University; retired since 2016.

Jörg Frey Geboren 1962; 1996 Promotion; 1998 Habilitation; Professur für neutestamentliche Wissenschaft mit den Schwerpunkten Antikes Judentum und Hermeneutik an der Theologischen Fakultät der Universität Zürich und Research Associate der University of the Free State, Bloemfontein/ZA.

https://orcid.org/0000-0001-6628-8834

Jetzt bestellen:

https://mohrsiebeck.com/buch/the-opening-of-johns-narrative-john-119-222-9783161556630?no_cache=1

order@mohrsiebeck.com

Telefon: +49 (0)7071-923-17

Telefax: $+49(0) 7071-51104$ 